\title{
Decaen and Linois
}

\section{John Leyland}

To cite this article: John Leyland (1911) Decaen and Linois, Royal United Services Institution. Journal, 55:397, 360-362, DOI: 10.1080/03071841109418039

To link to this article: http://dx.doi.org/10.1080/03071841109418039

$$
\text { 曲 Published online: } 11 \text { Sep } 2009 .
$$

Submit your article to this journal 4

Џll Article views: 1

Q View related articles $₫$ 


\section{DECAEN AND LINOIS.}

\section{By JOHN LEYLAND.}

ARCH EOLOGY, being the handmaid of History, may reasonably take account of minor circumstances which illustrate the flow of the historical stream. From this point of view the present article is written. Readers of naval history are awase of the unsatisfactory relations that existed' - between Rooke and Marlborough,' Byng and Blakeney, Vernon and Wentworth, and other naval and military commanders, and they know how fruitful of good results was the better understanding of Boscawen with Amherst and Wolfe', and of St. Vincent with Monckton and Grey. Here it is intended to throw some light upon the relations between the French naval and military services in the time of the First Consul, by describing certain incidents arising from the passage of General Decaen to Pondicherry and the lle de France in 1803.

In the previous year, when Decaen was an inspecting general of infantry, he proceeded to Toulon, where he had a heated discussion with Rear-Admiral Emmeriau, on the subject of the arrogant attitude which, he said, naval officers adopted in their dealings with officers of the army. On this subject he communicated with the Minister of War, and being dissatisfied with the results of a decision arrived at between the latter and Decrès, Minister of Marine, he reserved to himself the opportunity of discussing the matter with the First Consul on returning to Paris. He appears to have been refused admission to the arsenal at Toulon, and Decrès, who received him very coldly, said he had not presented himself in uniform. This he had denied, declaring that it was not his custom to lie. The treaty of Amiens had been signed, and Decaen was appointed Captain-General of the French establishments in India, and was directed to proceed with an expeditionary force to Pondicherry, to take over the possessions which were to be given up by the British under the terms of the Treaty. Decaen's own account of the proceedings will be found set forth in detail in the second volume of Lieut.-Colonel Ernest Picard's "Mémoires et Journaux du Général Decaen " (Plon-Nourrit, 1911).

The expedition was to consist of the Marengo, 74, bearing the flag of Rear-Admiral Linois, the frigates Belle Poule, Atalante, and Sémillante, with the flute Nécessité, and some transports, but Decres substituted for the flate a cramped merchantman named the Côte-d'Or. This circumstance led to an altercation with the Minister, and an appeal to Bonaparte. The troops, with functionaries, women, children, and others, ga, a total of 1,400 persons, but a battalion of 600 blacks and muli os was added, to be formed at Brest out of a body of some 1,500 
sent by Richepanse from Guadeloupe. When Decaen met Linois at Brest, antipathy; and even hostility, was soon revealed between the two officers. We know from Colonel Picard's book what the General thought of the Admiral, but not what the Admiral thought of the General. Decres had indicated a niggardly. course of action to Linois. He was not to allow to Decaen the accommodation which had been provided for other captainsgeneral, and especially to Leclerc. Too much money had been expended in luxury. This arrangement profoundly dissatisfied the General, who had with him his wife and one of her sisters, besides a brother and brother-in-law. He was obliged to buy at Brest bedding, furniture, linen, and table requisites and utensils.

At a meeting at the naval prefecture, Decaen told Caffarelli, the prefect, that rather than occupy the unworthy accommodation offered in the Marengo, he vould go with his family on board the despised Câte-d'Or. Linois, who was present, said the regulations provided that in a flagship, the captain must give up his own cabin, which was the first on the starboard side, and must accupy the first cabin on the larboard side, giving the place of honour to the Admiral. 'To which Decaen replied that, as he had himself some pretension to the most important position on board, they could not well contest his right to be second. "However, I have decided," he said, "to embark in the Côte $d^{\prime} O r$, and leave you to the plenitude of your regulations and your vessel!" This proposal horrified Caffarelli, who said it could not possibly be permitted, and it was finally decided that the General should have the Captain's cabin on the larboard, and such other cabins as he required on the same side, and as to the great cabin, if he was not prepared to share it with the Admiral, a partition could be placed down the middle. This latter arrangement was evidently not carried out.

Finally, the squadron put to sea on the $5^{\text {th }} \mathrm{March}, 1803$, in a lively breeze, and Decaen says that most of the naval officers, and the greater part of the crew, were sea-sick, and that Linois and Captain Larue could not leave their beds for twenty-four hours. Decaen curiously attributes his own immunity to the care he bestowed on his wife, his lively occupation of fixing in their places things that were liable to roll about, and the fact that he frequently went on deck to see what was going forward: He derides Linois as "our chef de pension," who provided a miserable table through extreme avarice, though he had received a considerable allowance. A thin little Breton cow and some infirm poultry had not survived their first experience of the sea, to which circumstance the Admiral attributed the famine that stared them in the face from the beginning. It gave Linois pleasure to accustom his guests to salt beef and pork, beans, and haricots, and almost to the food of the crew: He consoled them with the thought that plentiful provisions would be pro- 
curabie at the Cape of Good Hope. His wine was of poor quality. He personally supervised the arrangement of the table, setting out plates and chairs, and re-arranging them several times, and finally gave the carpenter instructions to make a table providing space for. 17 persons only. Decaen's brother and brother-in-law were excluded from this first table because they were not superior officers.

Arrived at Simon's Bay Linois found provisions too dear, but he provided a few radishes and a couple of eggs for each of his guests. According to Decaen the Marengo nearly ran ashore owing to the ignorance of Linois and his otticers. At this place there was an embittercd altercation between the Admiral and General, because the former allowed seamen to land, while he denied the privilege to soldiers, of whom some had been guilty of disorderly conduct on arrival. Ultimately he gave way. Captain Larue appears to have been a cautious seaman, afraid of the consequence for his masts and yards of carrying too much sail, and on this subject Decaen ridicules him, saying he was laughed at both by sailors and soldiers. Linois announced that he had made great purchases of provisions, but they appeared to consist merely of some poultry in cages, a few bushels of onions, and some mushrooms which hung in a net outside his stern-walk. Linois had orders not to stop at the Ile de France, and he would not exercise any discretionary power, whereby he might have taken in provisions, though his passengers besought him to do so.

The squadron had separated during the passage, but the Marengo arrived at Pondicherry on the it July, there to find the squadron of Commodore Rainier, and the Belle Poule lying between two British vessels. War had already broken out afresh, but news of the rupture of the peace of Amiens had not reached the East. Everything, however, tended to show that hostilities were imminent, and almost immediately the Bélicr brig arrived with despatches from the first Consul, written in March, reporting a great British armament to be in preparation, and ordering Linois to proceed to the Ile de France.

The object of this article is not to recount the course of events then or subsequently. The sole purpose has been to illustrate the relations which existed between French soldiers and sailors at the time, and some of the conditions of life in the French ships. Not everything was unsatisfactory. Decaen himself, speaks of a comedy enacted on board, of amusements in the fine weather, and of music nightly in the great cabin of the Marengo during the long passage. But of hearty co-operation between himself and Linois there was no trace, and their personal differences and quarrels were not without influence upon the greater events of the time. 